\title{
Synthesis and electrophysical properties of composite materials based on heterostructures $\mathrm{CuS} / \mathrm{CdS}, \mathrm{Cu}_{2} \mathrm{~S} / \mathrm{CdS}, \mathrm{Ag}_{2} \mathrm{~S} / \mathrm{CdS}$
}

\author{
S. L. Prokopenko • G. M. Gunja • S. N. Makhno • \\ P. P. Gorbyk
}

Received: 8 May 2014/Accepted: 9 July 2014/Published online: 30 July 2014

(c) The Author(s) 2014. This article is published with open access at Springerlink.com

\begin{abstract}
Polymer composite materials based on $\mathrm{CuS}$ / $\mathrm{CdS}, \mathrm{Cu}_{2} \mathrm{~S} / \mathrm{CdS}$ and $\mathrm{Ag}_{2} \mathrm{~S} / \mathrm{CdS}$ were obtained by substitution of $\mathrm{Cd}$ with $\mathrm{Ag}, \mathrm{Cu}$ (II) and $\mathrm{Cu}$ (I) ions in the $\mathrm{CdS}$ rodlike nanocrystalline and investigated their electrophysical properties. It was found that the electrical conductivity of $\mathrm{CuS} / \mathrm{CdS}$ heterostructure is in five orders higher compared to the CdS. It was shown that the values of the complex permittivity at identical content of $\mathrm{CuS}$ and $\mathrm{Cu}_{2} \mathrm{~S}$ nanoparticles are more than $40 \%$ higher for the $0.3 \mathrm{Cu}_{2} \mathrm{~S} / \mathrm{CdS}$ PVDF system in comparison with the $0.3 \mathrm{CuS} / \mathrm{CdS}-\mathrm{PVDF}$.
\end{abstract}

Keywords Compositional materials · Disperse filler · Polyvinylidene fluoride

\section{Introduction}

Synthesis and study of semiconductor nanoparticles of various metal sulfides are developing rapidly due to the unique photoelectric properties and a wide use of these compounds in various fields [1, 2]. Through development of the nanocrystalline heterostructures researchers can achieve low-cost synthesis and the possibility to use them in various fields, particularly in specific biological markers [3, 4], broadband light-emitting diodes [5] and highly efficient solar batteries [6]. Various methods of synthesis of $\mathrm{CuS}$ nanostructures with different morphology were developed such as hydrothermal [7], microwave assisted [8] and template synthesis [9]. By tuning of the synthesis

S. L. Prokopenko $(\bowtie) \cdot$ G. M. Gunja · S. N. Makhno ·

P. P. Gorbyk

Chuiko Institute of Surface Chemistry, NAS of Ukraine, General

Naumov Street 17, Kiev 164 03164, Ukraine

e-mail: sprokop@yandex.ru conditions, nanostructures with different aspect number can be obtained such as nanoparticles, nanowires, nanorods, nanofibers. Therefore, synthesis of new materials with nanoscale heterojunction and the study of their electrical properties within wide range of frequencies and temperatures is an important task.

\section{Materials and methods}

Semiconductor heterostructures $\mathrm{Ag}_{2} \mathrm{~S} / \mathrm{CdS}, \mathrm{CuS} / \mathrm{CdS}$ and $\mathrm{Cu}_{2} \mathrm{~S} / \mathrm{CdS}$ were prepared during the two-stage synthesis. Previously $\mathrm{CdS}$ nanowires were synthesized by crystallization of $0,004 \mathrm{M} \mathrm{Cd}\left(\mathrm{NO}_{3}\right)_{2} \bullet 4 \mathrm{H}_{2} \mathrm{O}$ (analytical grade, GOST 6262-79) and 0,008 $\mathrm{M}$ thiourea (analytical grade, GOST 6344-73) from ethylenediamine $\mathrm{C}_{2} \mathrm{H}_{4}\left(\mathrm{NH}_{2}\right)_{2}$ (analytical grade, TU 6-09-10-645-77) (30 ml) at $393 \mathrm{~K}$ (Fig. 1). After cooling to the ambient temperature, the precipitate was washed with distilled water, centrifuged and dried at $330 \mathrm{~K}$. The residual content of copper ions in the solution was determined spectrophotometrically utilizing complexation reactions with $\mathrm{Cu}$ (I) and $\mathrm{Cu}$ (II) [10]. Subsequently heterostructures such as $\mathrm{Ag}_{2} \mathrm{~S} / \mathrm{CdS}, \mathrm{CuS} / \mathrm{CdS}$ and $\mathrm{Cu}_{2} \mathrm{~S} / \mathrm{CdS}$ were prepared by substitution of $\mathrm{Cd}$ ions by $\mathrm{Ag}, \mathrm{Cu}$ (II) and $\mathrm{Cu}$ (I) ions, respectively. Reactions of ions substitution were performed at $295 \mathrm{~K}$ in solutions of $\mathrm{AgNO}_{3}, \mathrm{CuSO}_{4} \bullet 5 \mathrm{H}_{2} \mathrm{O}$ and $\mathrm{Cu}_{2} \mathrm{O}$ according to the procedure.

Polymeric composite materials were prepared by mixing polyvinylidene fluoride (PVDF) with the semiconductor powder $\left(\mathrm{Ag}_{2} \mathrm{~S} / \mathrm{CdS}, \mathrm{CuS} / \mathrm{CdS}\right.$ and $\mathrm{Cu}_{2} \mathrm{~S} / \mathrm{CdS}$ obtained in this work) by grinding in the mechanical mill to form a homogeneous mixture, which thereafter was compressed at the polymer melt temperature. 


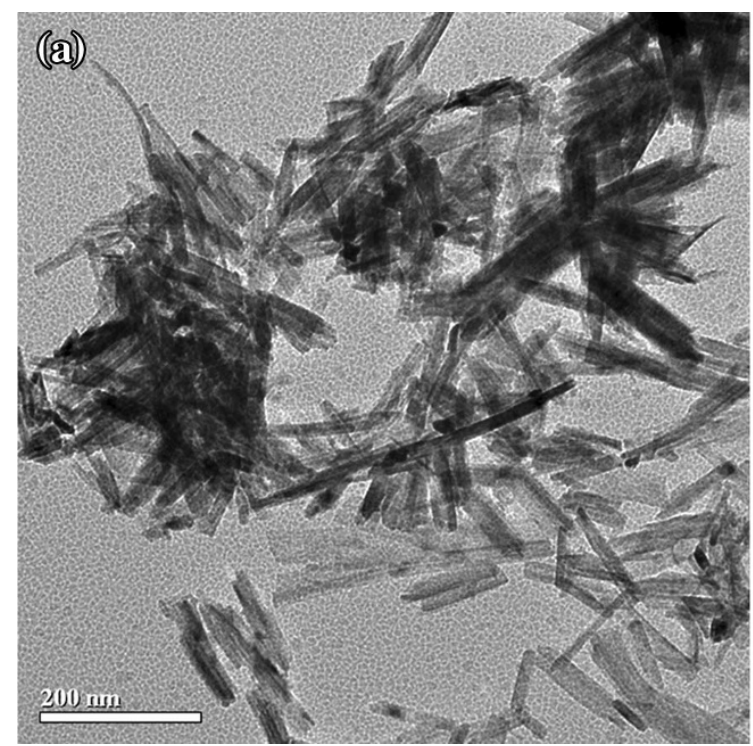

Fig. 1 TEM images of nanorods: CdS (a) and $0.85 \mathrm{CuS} / \mathrm{CdS}(\mathbf{b})$

Crystal structure was determined using X-ray analysis (DRON-4-07, Lomo, USSR) in the emission of copper cathode with nickel filter in Bragg-Brentano geometry. Images were obtained using transmission electron microscope JEM-2100F (Jeol, Japan).

The real $\left(\sigma^{\prime}\right)$ and imaginary $\left(\sigma^{\prime \prime}\right)$ components of the complex electrical conductivity at low frequencies $(0.1,1$ and $10 \mathrm{kHz}$ ) were measured using the immittance meter E7-14 by two-contacts method in the temperature range from 295 to $355 \mathrm{~K}$. The frequency dependence of the electrical conductivity was measured by an impedance spectrometer Solortron SI 1260 (Solortron analytical, UK) in the frequency range $10^{-2}-10^{6} \mathrm{~Hz}$. The real $\left(\varepsilon^{\prime}\right)$ and imaginary $\left(\varepsilon^{\prime \prime}\right)$ components of the complex permittivity in microwave (MW) range were measured using the interferometer at a frequency of $9 \mathrm{GHz}$ [11].

\section{Results and discussions}

The formation of CdS nanorods in ethylenediamine was carried out according to the following equation

$n C d^{2+}+2 n(E D A) \leftrightarrow n\left[C d(E D A)_{2}\right]^{2+}$

$n\left[C d(E D A)_{2}\right]^{2+}+n S^{2-} \stackrel{E D A}{\leftrightarrow}(C d S) n$

Cd ions from a solution of $\mathrm{Cd}\left(\mathrm{NO}_{3}\right)_{2} \bullet 4 \mathrm{H}_{2} \mathrm{O}$ react with ethylenediamine ligands to form a relatively stable complex (1), which under certain synthesis conditions promote a crystal growth into a rod-like structure [12].

TEM images of the CuS/CdS heterostructure with $85 \mathrm{~mol} \%$ substitution of $\mathrm{Cd}$ ions by $\mathrm{Cu}$ ions $(0.85 \mathrm{CuS} /$ CdS) showing rods with an average length of 150-200 nm, and a thickness approximately of $20 \mathrm{~nm}$ (Fig. 1.2).
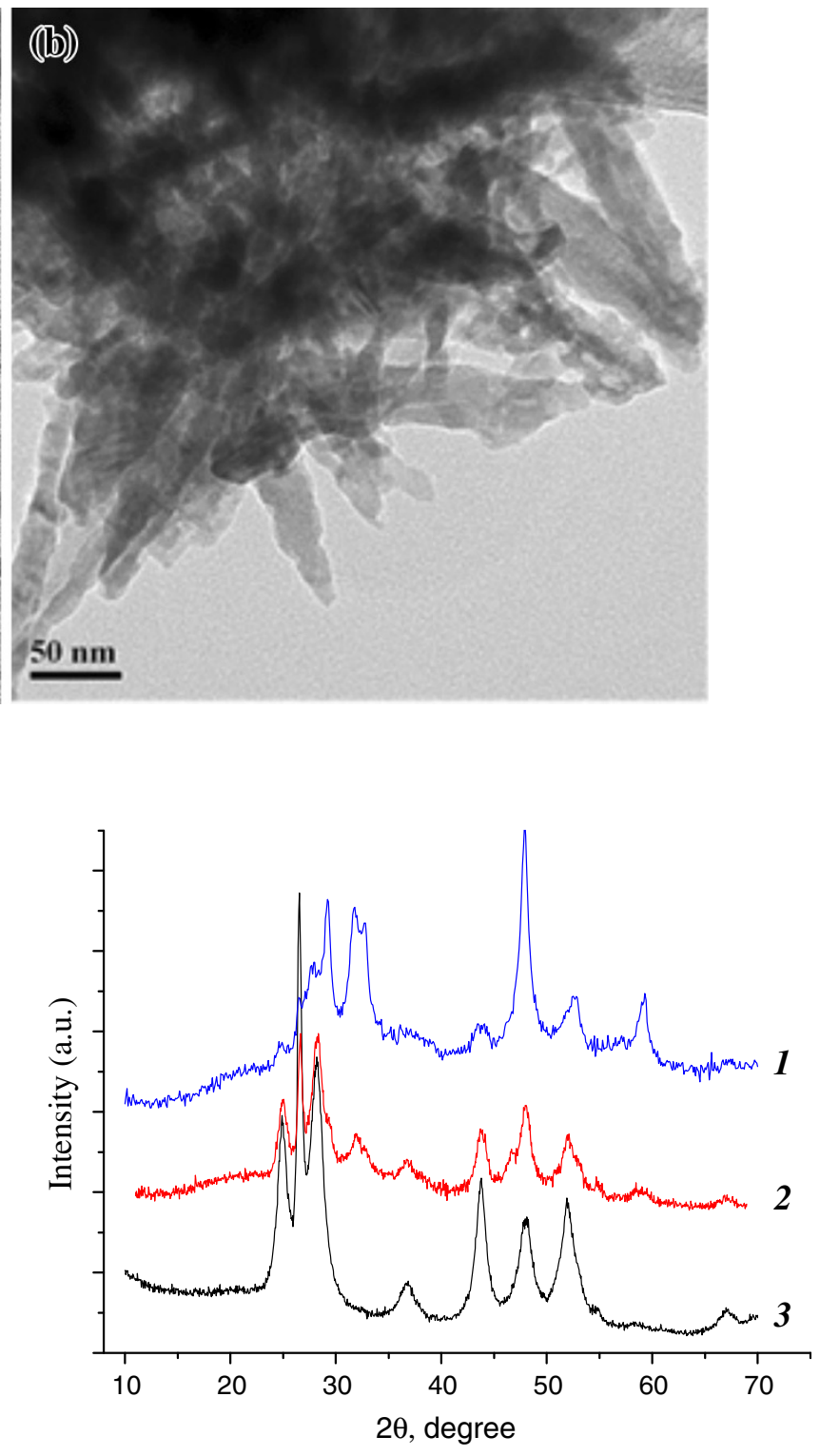

Fig. 2 X-ray diffraction patterns of heterostructures: $1-0.3 \mathrm{CuS} /$ $\mathrm{CdS}, 2-0.3 \mathrm{Cu}_{2} \mathrm{~S} / \mathrm{CdS}, 3-\mathrm{CdS}$

Identification of the structure characteristics was performed using diffraction patterns. XRD graphs show diffraction peaks, which indicate the formation of heterostructures of $\mathrm{CuS} / \mathrm{CdS}(1)$ and $\mathrm{Cu}_{2} \mathrm{~S} / \mathrm{CdS}$ (2) (Fig. 2). $\mathrm{XRD}$ spectra of the obtained $\mathrm{CuS} / \mathrm{CdS}$ heterostructure is in good correspond with CdS (JCPDS 75-1545) and CuS (JCPDS 78-0878) in a hexagonal phase (Fig. 2.1). The heterostructure of $\mathrm{Cu}_{2} \mathrm{~S} / \mathrm{CdS}$ consists of a nanorod $\mathrm{CdS}$ with cubic $\mathrm{Cu}_{2} \mathrm{~S}$ (JCPDS 84-1770) on the surface (Fig. 2.2). In the spectra of the $\mathrm{CuS} / \mathrm{CdS}$ heterostructure (Fig. 2.1), an amorphous halo (15-24 $2 \theta$ degree) has a higher intensity comparing with halo in the spectra of $\mathrm{Cu}_{2} \mathrm{~S} / \mathrm{CdS}$ (Fig. 2.2), that indicates less ordered crystalline structure. 


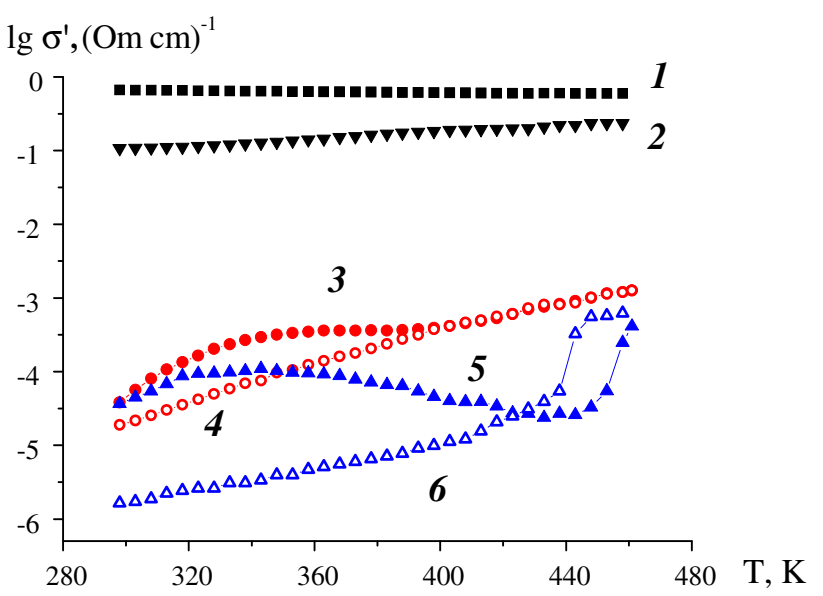

Fig. 3 Temperature dependence of the logarithm of electrical conductivity of synthesized heterostructures: $1-0.85 \mathrm{CuS} / \mathrm{CdS}, 2-$ $0.15 \mathrm{CuS} / \mathrm{CdS}, 3-\mathrm{CdS}$ (heating), 4- CdS (cooling), 5-0.85 $\mathrm{Ag}_{2} \mathrm{~S} /$ $\mathrm{CdS}$ (heating), 6- $0.85 \mathrm{Ag}_{2} \mathrm{~S} / \mathrm{CdS}$ (cooling)

Temperature dependence of the electrical conductivity $\left(\sigma^{\prime}\right)$ for the $\mathrm{CuS} / \mathrm{CdS}$ heterostructure (not shown here), which was synthesized by substitution of $50 \% \mathrm{Cd}$ ions by $\mathrm{Cu}$ ions, almost coincides with the temperature dependence of the $\sigma^{\prime}$ for the $0.85 \mathrm{CuS} / \mathrm{CdS}$ heterostructure (Fig. 3.1) therefore indicates a high level of electrical conductivity. A significant increase in the electrical conductivity of $\mathrm{CuS} /$ CdS nanorods at low $(\sim 15 \%)$ substitution of $\mathrm{Cd}$ ions by $\mathrm{Cu}$ ions (Fig. 3.2) compared with $\mathrm{CdS}$ (Fig. 3.4) was observed. Value $\sigma^{\prime}$ of the heterostructure semiconductor $0.85 \mathrm{CuS} / \mathrm{CdS}$ and $0.15 \mathrm{CuS} / \mathrm{CdS}$ differs only by the order and exceeds the values $\sigma^{\prime}$ for CdS in about of 4-5 orders in magnitude, indicating the achievement of percolation threshold for these composites above of which the conductivity is mainly related to transfer charges through the $\mathrm{CuS}$.

(a)

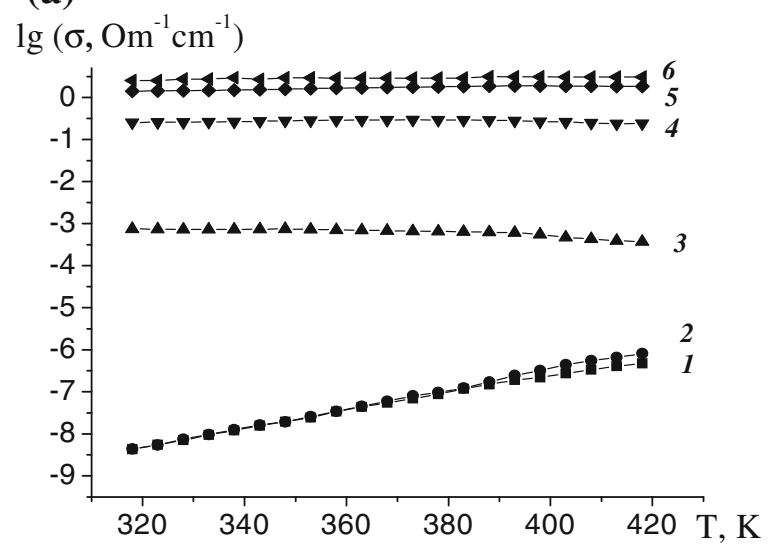

The $\mathrm{Ag}_{2} \mathrm{~S} / \mathrm{CdS}$ heterostructure has another character of dependencies. Fig. 3 shows the reduction in values of the $\sigma^{\prime}$ for $0.85 \mathrm{Ag}_{2} \mathrm{~S} / \mathrm{CdS}$ composite (Fig. 3.5, 6) in comparison with CdS (Fig. 3.3). This may indicate a partial destruction of CdS rods during the ion exchange. Sudden increase in the conductivity about $450 \mathrm{~K}$ (Fig. 3.5, 6) caused by the phase transition of the $\mathrm{Ag}_{2} \mathrm{~S}$ from the monoclinic in a cubic syngony. Curves of the temperature dependence of $\sigma^{\prime}$ for nanorods $\mathrm{CdS}$ and the $0.85 \mathrm{Ag}_{2} \mathrm{~S} / \mathrm{CdS}$ heterostructure (Fig. 3.3, 5) show a maxima about of $355 \mathrm{~K}$ under heating, which correspond to the water desorption from the surface. Those maxima are disappearing when samples are cooled and curves (Fig. 3.4, 6) have a linear character in the semi-logarithmic scale.

The temperature dependence of the electrical conductivity of polymer composite materials $0.3 \mathrm{Cu}_{2} \mathrm{~S} / \mathrm{CdS}$-PVDF and $0.3 \mathrm{CuS} / \mathrm{CdS}-\mathrm{PVDF}$ at $1 \mathrm{kHz}$ (Fig. 4) possesses similar characteristics for both systems. Figure 4 shows a slight decrease of $\sigma^{\prime}$ with an increase of temperature on curves 4 , 5 and 6 . Such character of the temperature dependence of $\sigma^{\prime}$ is typical for metals and for crystalline $\mathrm{CuS}$ and $\mathrm{Cu}_{2} \mathrm{~S}$. With an increase of the temperature for composites in which contain of the $\mathrm{Cu}_{2} \mathrm{~S}$ (or $\mathrm{CuS}$ ) in the polymer is corresponds to the percolation threshold (Fig. 4a, b; curves 1,2 and 3) an increase of conductivity values was observed. The character of the temperature dependence of conductivity is described by the Arrhenius' equation

$\sigma(\mathrm{T})=\sigma_{0} \exp \left(-\mathrm{E}_{\mathrm{a}} / 2 \mathrm{kT}\right)$

where $\mathrm{E}_{\mathrm{a}}-$ the activation energy of conductivity, $\sigma_{0}-$ parameter that depends on the nature of the semiconductor, $\mathrm{k}$ - the Boltzmann constant and $\mathrm{T}$-temperature.

Until the percolation threshold content, the electrical conductivity is determined by the tunneling of the charge through the barrier at the interface, which is caused by the

(b)

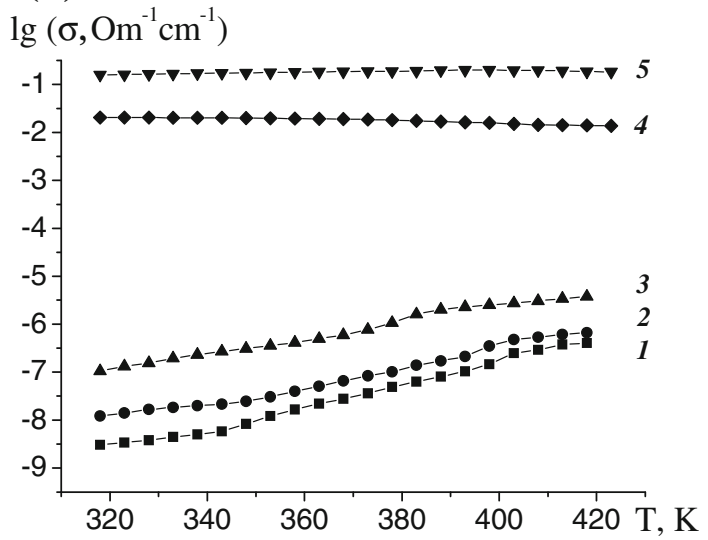

Fig. 4 Dependence of conductivity on temperature for composites $0.3 \mathrm{Cu}_{2} \mathrm{~S} / \mathrm{CdS}-\mathrm{PVDF}(\mathbf{a})$ and $0.3 \mathrm{CuS} / \mathrm{CdS}-\mathrm{PVDF}(\mathbf{b})$ with volume content $\mathrm{Cu}_{2} \mathrm{~S}$ and $\mathrm{CuS}$ : $1-0.015 ; 2-0.03 ; 3-0.06 ; 4-0.09 ; 5-0.12 ; 6-0.15$ 


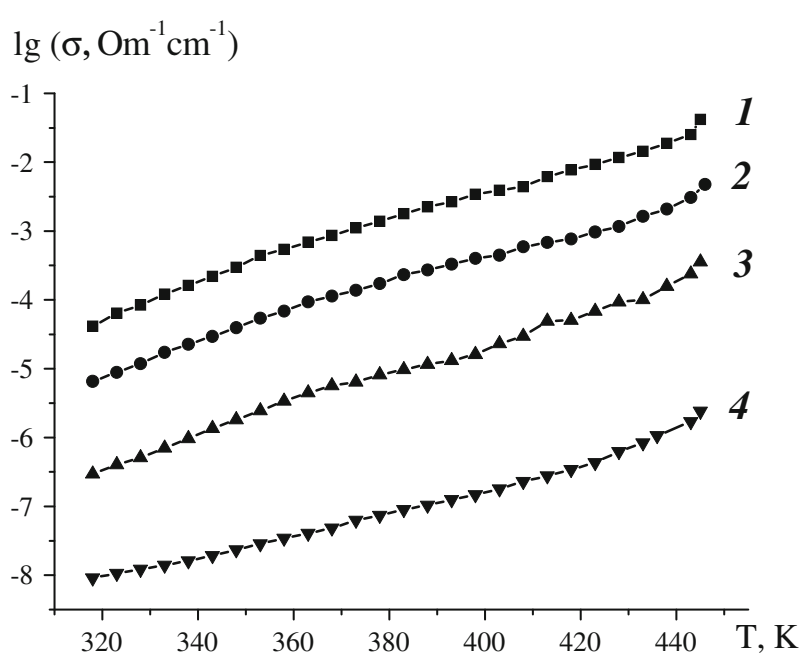

Fig. 5 Dependence of conductivity on temperature for the system $0.85 \mathrm{Ag}_{2} \mathrm{~S} / \mathrm{CdS}-\mathrm{PVDF}$ with volume content $\mathrm{Ag}_{2} \mathrm{~S}: 1-0.25,2-0.15$, $3-0.08,4-0.05$

presence of thin polymer layers and depends on the distance between particles and the dielectric constant of the polymer matrix. Therefore, with the temperature increase the electron's energy in composites will increase, and most of the electrons will tunnel through the dielectric layers.

Curves of the temperature dependence of the electrical conductivity for $0.85 \mathrm{Ag}_{2} \mathrm{~S} / \mathrm{CdS}-\mathrm{PVDF}$ are shown in Fig. 5. For all composites, the electrical conductivity is increases with an increase of the temperature. An increase of the electrical conductivity at $445 \mathrm{~K}$ is associated with the beginning of the phase transition of the $\mathrm{Ag}_{2} \mathrm{~S}$ from the monoclinic to the cubic syngony.

Graphs of the frequency dependence of conductivity for the CdS are shown in Fig. 6a. The real part of the complex conductivity $\left(\sigma^{\prime}\right)$ of $\mathrm{CdS}$ rods increases monotonically along with rise of the frequency. After $10^{6} \mathrm{~Hz}$, the value of $\sigma^{\prime}$ rises dramatically (Fig. 6a, 1) which is due to the resonant process that corresponds to the change between capacitive and inductive character of impedance of the sample the structural units of which are rods.
Extrapolation of the low-frequency part of the graph (Fig. 6a, 1) towards to lower frequencies gives the value $\sigma_{\mathrm{DC}}$ of $2 \bullet 10^{-8} \mathrm{Om}^{-1} \mathrm{~cm}^{-1}$. The real component of the conductivity can be described by the degree dependence, which corresponds to the jumping mechanism of charge transfer between the CdS rods and given as an equation

$\sigma^{\prime}(\omega)=\sigma_{\mathrm{DC}}^{\prime}\left(1+\left(\omega / \omega_{\mathrm{H}}\right)^{\mathrm{n}}\right)$,

where $\sigma_{\mathrm{DC}}^{\prime}-$ the DC conductivity, $\omega_{H}$-the frequency of jump of the charge and $n$-the dimensionless parameter [13].

The frequency dependence of the real and apparent components of the complex conductivity of the $\mathrm{CuS} / \mathrm{CdS}$ rod-like semiconductor heterostructures (Fig. 6b) indicates a frequency-independent character of values in a wide range of frequencies (below $10^{4} \mathrm{~Hz}$ ). The negative values of the $\sigma^{\prime \prime}$ indicate the inductive character of conductivity. Inductive nature of conductivity changes to capacitive with degrees of substitution of $\mathrm{Cd}$ ions with $\mathrm{Cu}$ ions $(<15 \%)$. With this degree of substitution, the percolation threshold of $\mathrm{CuS}$ is reached, i.e., current continuously flows along the rods of the heterostructure.

The dependence of the complex permittivity of $0.3 \mathrm{CuS} /$ CdS-PVDF and $0.3 \mathrm{Cu}_{2} \mathrm{~S} / \mathrm{CdS}-\mathrm{PVDF}$ systems of the volume content of $\mathrm{CuS}$ and $\mathrm{Cu}_{2} \mathrm{~S}$ is shown in Fig. 7. Prior to the percolation threshold, values of complex permittivity for $0.3 \mathrm{CuS} / \mathrm{CdS}-P V D F$ and $0.3 \mathrm{Cu}_{2} \mathrm{~S} / \mathrm{CdS}-P V D F$ had the same order in magnitude. After exceeding the percolation threshold, the value of the complex permittivity for the $0.3 \mathrm{Cu}_{2} \mathrm{~S} / \mathrm{CdS}-\mathrm{PVDF}$ is increasing comparing with $0.3 \mathrm{CuS} / \mathrm{CdS}-\mathrm{PVDF}$, and at a volume content of $0.15(\mathrm{CuS}$ or $\mathrm{Cu}_{2} \mathrm{~S}$ ) the difference is about of $40 \%$.

Curves of dependence of the electrical conductivity for $0.3 \mathrm{Cu}_{2} \mathrm{~S} / \mathrm{CdS}-\mathrm{PVDF}$ and $0.3 \mathrm{CuS} / \mathrm{CdS}-\mathrm{PVDF}$ (Fig. 8) shows that until a percolation threshold the conductivity of $0.3 \mathrm{Cu}_{2} \mathrm{~S} / \mathrm{CdS}-\mathrm{PVDF}$ systems has lower value than for $0.3 \mathrm{CuS} / \mathrm{CdS}-\mathrm{PVDF}$. For these systems, a percolation threshold is described by the equation:

$\sigma(\Theta)=\sigma_{0}\left(\Theta-\Theta_{c}\right)^{\mathrm{t}}$
Fig. 6 The frequency dependence of the electrical conductivity of $\mathrm{CdS}$ nanorods a and heterostructures $0.85 \mathrm{CuS} / \mathrm{CdS} \mathbf{b}\left(1-\sigma^{\prime}, 2-\sigma^{\prime \prime}\right)$ (a)

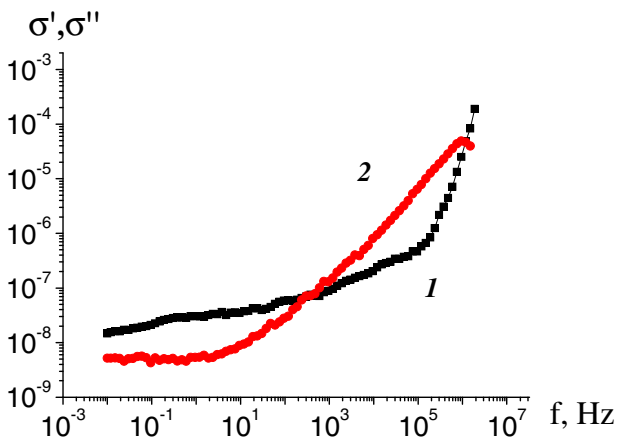

(b)

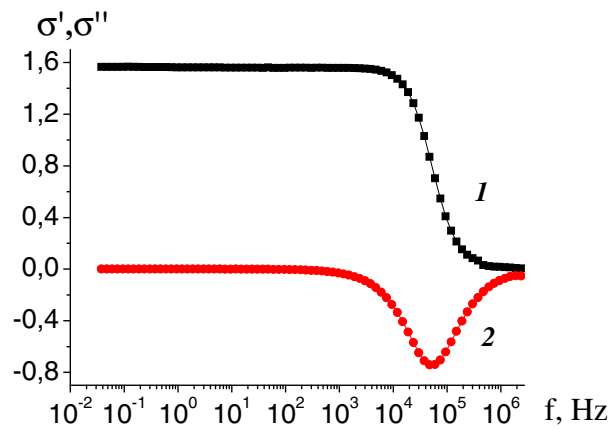




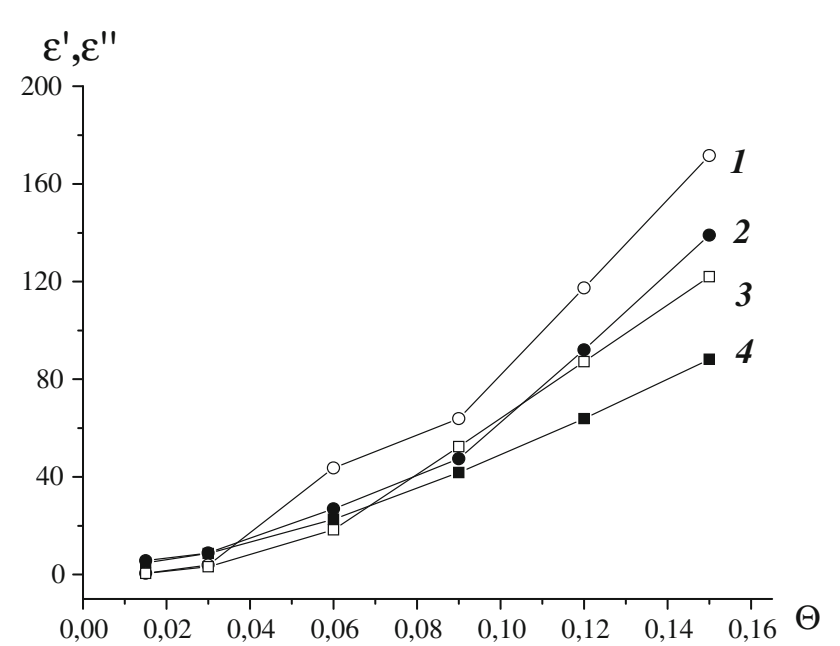

Fig. 7 The dependence of $\varepsilon^{\prime}(2,4)$ and $\varepsilon^{\prime \prime}(1,3)$ of the volume content of nanocrystalline $\mathrm{Cu}_{2} \mathrm{~S}$ in the $0.3 \mathrm{Cu}_{2} \mathrm{~S} / \mathrm{CdS}$-PVDF system $(1,2)$ and $\mathrm{CuS}$ in the $0.3 \mathrm{CuS} / \mathrm{CdS}-\mathrm{PVDF}$ system $(3,4)$ at a frequency of $9 \mathrm{GHz}$

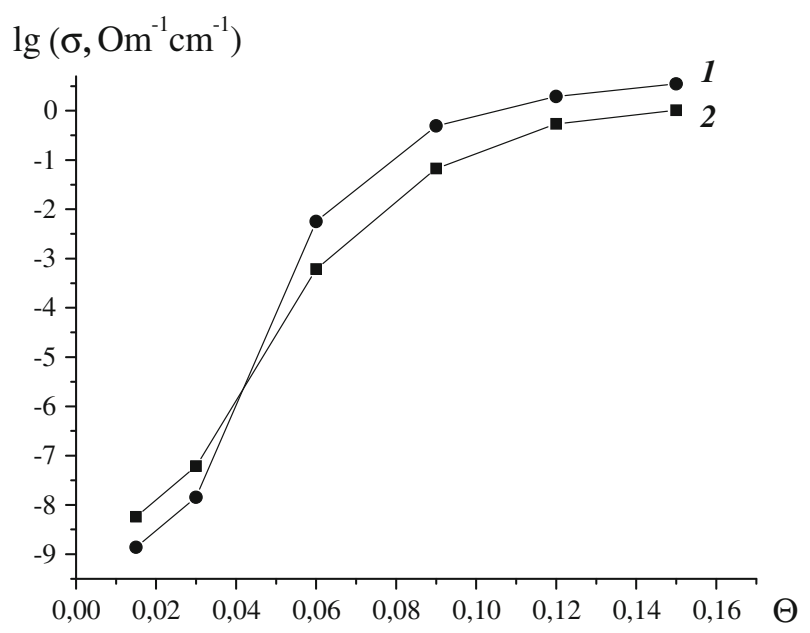

Fig. 8 Dependence of conductivity of $0.3 \mathrm{Cu}_{2} \mathrm{~S} / \mathrm{CdS}-\mathrm{PVDF}(1)$ and $0.3 \mathrm{CuS} / \mathrm{CdS}-\mathrm{PVDF}$ (2) systems in regards to the content of $\mathrm{CuS}$ and $\mathrm{Cu}_{2} \mathrm{~S}$, at $1 \mathrm{kHz}$

where $\Theta_{c}$ - the content of filler in the composite, which corresponds to a percolation threshold, $\mathrm{t}$-is exponential quantity and $\sigma_{0}$-the electrical conductivity of the conductive component (Table 1).

After achieving of the percolation threshold, the value of electrical conductivity for $0.3 \mathrm{Cu}_{2} \mathrm{~S} / \mathrm{CdS}$-PVDF is five times higher than the same for $0.3 \mathrm{CuS} / \mathrm{CdS}-\mathrm{PVDF}$. This indicates that the $0.3 \mathrm{CuS} / \mathrm{CdS}-\mathrm{PVDF}$ system has a higher degree of dispersion; therefore, the greater number of contacts between particles and the contact resistance between them are crucial. Prior to the percolation threshold, the higher degree of dispersion increases the
Table 1 Values of a percolation threshold and the critical exponent for $0.3 \mathrm{Cu}_{2} \mathrm{~S} / \mathrm{CdS}-\mathrm{PVDF}$ and $0.3 \mathrm{CuS} / \mathrm{CdS}-\mathrm{PVDF}$ systems

\begin{tabular}{llll}
\hline System & $\Theta_{\mathrm{c}}$ & $t$ & $\sigma_{0}$ \\
\hline $0.3 C u_{2} S / C d S-P V D F$ & 0.05 & 2.7 & $2.5 * 10^{3}$ \\
$0.3 C u S / C d S-P V D F$ & 0.05 & 3.1 & $1.5^{*} 10^{3}$ \\
\hline
\end{tabular}

conductivity of the system by reducing the thickness of the polymer layers and consequently increases the probability of electron tunneling through the potential barrier. Hence, the use of $\mathrm{CuS} / \mathrm{CdS}$ as a conductive component in polymer composites is effective for low-filled systems and $\mathrm{Cu}_{2} \mathrm{~S} /$ CdS—for high-filled systems.

\section{Conclusion}

Semiconductor heterostructures of $\mathrm{CuS} / \mathrm{CdS}, \mathrm{Cu}_{2} \mathrm{~S} / \mathrm{CdS}$, and $\mathrm{Ag}_{2} \mathrm{~S} / \mathrm{CdS}$ were obtained by the substitution of $\mathrm{Cd}$ with $\mathrm{Ag}, \mathrm{Cu}$ (II) and $\mathrm{Cu}$ (I) ions in the $\mathrm{CdS}$ rod-like nanocrystalline. The resulting semiconductor heterostructure possess the aspect ratio $>10$ and electrical properties of such semiconductor heterostructures were investigated. It was also found that the electrical conductivity of $\mathrm{CuS} / \mathrm{CdS}$ heterostructure is in five orders higher being compared to the CdS. It was shown that the values of the complex permittivity at identical content of $\mathrm{CuS}$ and $\mathrm{Cu}_{2} \mathrm{~S}$ nanoparticles are more than $40 \%$ higher for the $0.3 \mathrm{Cu}_{2} \mathrm{~S} / \mathrm{CdS}$ PVDF system compared with the $0.3 \mathrm{CuS} / \mathrm{CdS}-\mathrm{PVDF}$; the electrical conductivity value of the $0.3 \mathrm{Cu}_{2} \mathrm{~S} / \mathrm{CdS}-\mathrm{PVDF}$ is five times higher than the $0.3 \mathrm{CuS} / \mathrm{CdS}-\mathrm{PVDF}$ due to the formation of a more ordered crystalline structure. For $0.3 \mathrm{Cu}_{2} \mathrm{~S} / \mathrm{CdS}-\mathrm{PVDF}$ and $0.3 \mathrm{CuS} / \mathrm{CdS}-\mathrm{PVDF}$ composites after percolation threshold of the nanocrystalline $\mathrm{CuS}$ and $\mathrm{Cu}_{2} \mathrm{~S}$, the metallic character of conductivity was observed at higher temperatures.

Open Access This article is distributed under the terms of the Creative Commons Attribution License which permits any use, distribution, and reproduction in any medium, provided the original author(s) and the source are credited.

\section{References}

1. Gunes, S., Neugebauer, H., Sariciftci, N.S.: Conjugated polymerbased organic solar cells. Chem. Rev. 107, 1324-1338 (2007)

2. Grätzel, M.: Recent advances in sensitized mesoscopic solar cells. Acc. Chem. Res. 42, 1788-1798 (2009)

3. Bruchez, M., Moronne, M., Gin, P., Weiss, S., Alivisatos, A.P.: Semiconductor nanocrystals as fluorescent biological labels. Science 281(5385), 2013-2016 (1998)

4. Chan, W.C.W., Nie, S.M.: Quantum dot bioconjugates for ultrasensitive nonisotopic detection. Science 281(5385), 2016-2018 (1998) 
5. Achermann, M., Petruska, M.A., Kos, S., Smith, D.L., Koleske, D.D., Klimov, V.I.: Energy-transfer pumping of semiconductor nanocrystals using an epitaxial quantum well. Nature 429 , 642-646 (2004)

6. Gur, I., Fromer, N.A., Geier, M.L., Alivisatos, A.P.: Air-stable all-inorganic nanocrystal solar cells processed from solution. Science 310(5747), 462-465 (2005)

7. Zhang, X., Wang, G., Gu, A., Wei, Y., Fang, B.: CuS nanotubes for ultrasensitive nonenzymatic glucose sensors. Chem. Commun. 45, 5945-5947 (2008)

8. Chung, J.-S., Sohn, H.-J.: Electrochemical behaviors of $\mathrm{CuS}$ as a cathode material for lithium secondary batteries. J. Power Sources 108, 226-231 (2002)
9. Feng, X., Li, Y., Liu, H., Li, Y., Cui, S., Wang, N., Jiang, L., Liu, X., Yuan, M.: Controlled growth and field emission properties of CuS nanowalls. Nanotechnol. 18, 145706 (2007)

10. Marchenko, Z.: Photometric determination of the elements. Mir, Moscow (1971)

11. Ganiuk, L.N., Ignatkov, V.D., Makhno, S.N., Soroka, P.N.: Study of dielectric properties of the fibrous material. Ukr. Phys. J. 40(6), 627-629 (1995)

12. Zhao, Q., Hou, L., Huang, R., Li, S.: Surfactant-assisted growth and characterization of CdS nanorods. Inorg. Chem. Commun. 6, 1459-1462 (2003)

13. Almond, D.P., West, A.R.: Anomalous conductivity prefactors in fast ion conductors. Nature 306(5940), 456-457 (1983) 